\title{
The effect of intramammary infection in early lactation with non-aureus staphylococci in general and Staphylococcus chromogenes specifically on quarter milk somatic cell count and quarter milk yield
}

\author{
D. Valckenier, ${ }^{1} \odot$ S. Piepers, ${ }^{1} \odot$ A. De Visscher, ${ }^{1,2}$ and S. De Vliegher ${ }^{1 *} \odot$ \\ ${ }^{1}$ M-team \& Mastitis and Milk Quality Research Unit, Department of Reproduction, Obstetrics and Herd Health, Faculty of Veterinary Medicine, \\ Ghent University, B-9820 Merelbeke, Belgium \\ ${ }^{2}$ Flanders Research Institute for Agriculture, Fisheries, and Food (ILVO), Technology and Food Science, Agricultural Engineering, \\ B-9820 Merelbeke, Belgium
}

\section{ABSTRACT}

This longitudinal study aimed to evaluate the impact of subclinical intramammary infection (IMI) with nonaureus staphylococcal (NAS) species in the first $18 \mathrm{~d}$ in milk (DIM) on the quarter milk somatic cell count (qSCC) and quarter milk yield (qMY) during the first 4 mo of lactation in Holstein Friesian heifers. Quarter milk samples were collected from 82 heifers from 1 to 4 DIM until 130 DIM on a biweekly (14 d) basis for determination of the qSCC; qMY data were available through the automatic milking systems. The quarter samples collected on the first (1-4 DIM) and second (15-18 DIM) sampling days were used for bacteriological culturing to determine the IMI status. In this study, 324 quarters from 82 heifers were enrolled, of which 68 were NAS-infected at the first sampling day. Only 16 $(23.5 \%)$ of these quarters were still NAS-infected at the second sampling day, demonstrating the high spontaneous cure rate of these infections shortly after calving; 9 of these 16 cases were infected with the same NAS species. Interestingly, none of the NAS-infected quarters at the first sampling day acquired a new infection with a major pathogen at the second sampling day, whereas $2.3 \%$ of the noninfected quarters did. All 102 isolates phenotypically identified as NAS were further identified to the species level. Staphylococcus chromogenes was the most prevalent species on the first $(29.4 \%$ of all NAS) and second (52.9\%) sampling days. Quarters infected with Staph. chromogenes at the first sampling day had a significantly higher qSCC in later lactation than noninfected quarters, whereas this was not true for quarters infected with all other NAS species (i.e., as a group of species). The average daily qMY in the first

Received April 17, 2019.

Accepted September 8, 2019.

*Corresponding author: Sarne.Devliegher@UGent.be
4 mo of lactation did not differ between noninfected quarters and quarters infected with Staph. chromogenes or all other NAS species at the first sampling day. Persistently NAS species-infected quarters in the first 18 DIM (i.e., infected with the same NAS species on the first and second sampling days) had the highest qSCC later in lactation, followed by quarters with a new NAS IMI (i.e., noninfected at the first sampling day and infected with NAS at the second sampling day). The qSCC from transiently NAS species-infected quarters (i.e., not infected with the same NAS species at the second sampling day) was not significantly higher in later lactation compared with that in noninfected quarters. The IMI status of quarters in the first 18 DIM, combining culture results at 1 to 4 and 15 to 18 DIM (new, persistent, and transient IMI), was not significantly associated with daily qMY in the first 4 mo after calving. In general, NAS should be considered minor pathogens with no adverse effect on daily qMY in quarters of heifers infected in the first 18 DIM and with a high spontaneous cure rate. Staphylococcus chromogenes was the most prevalent species, causing an increase in qSCC comparable to the level of quarters infected with a major pathogen; Staph. chromogenes caused most infections that persisted through at least the first 18 DIM.

Key words: non-aureus staphylococci, species-specific infections, quarter milk yield, quarter somatic cell count

\section{INTRODUCTION}

As a group, the NAS are the most prevalent (ranging from 9.1 to $16.6 \%$ of milk samples) causative agents of IMI in dairy cows in many regions (Wilson et al., 1997; Pitkälä et al., 2004; Tenhagen et al., 2006), and are typically more isolated from subclinical than from clinical cases of mastitis (Persson Waller et al., 2011; Heikkilä et al., 2018). The relevance of NAS IMI with regard to the effect on milk production in affected 
quarters is still under debate as inconsistent results have been reported (Timms and Schultz, 1987; Gröhn et al., 2004; Taponen et al., 2006; Schukken et al., 2009; Paradis et al., 2010). Part of the contradiction can be attributed to differences in the length of the follow-up period, breed, parity, diagnostic methods, and definition of IMI status among the studies. More recent studies, considering only heifers (Valckenier et al., 2019) or cows of all parities (Tomazi et al., 2015; Heikkilä et al., 2018), still consider NAS (as a group) to be minor pathogens, only slightly elevating the quarter milk SCC (qSCC) in case of subclinical mastitis, and with little or no effect on the quarter milk yield (qMY).

The inconclusive results might also be, at least partly, explained by the diversity of this group of bacteria. Over 50 species and subspecies have been identified (http://www.bacterio.net/staphylococcus.html, accessed April 10, 2019), of which more than 19 have been isolated from bovine milk samples (Capurro et al., 2009; Tomazi et al., 2014; Vanderhaeghen et al., 2014; De Visscher et al., 2016). In many countries (reviewed by Vanderhaeghen et al., 2015), Staphylococcus (Staph.) chromogenes is the most prevalent species in milk samples from healthy primi- and multiparous cows and animals with subclinical (SCM) or clinical (CM) mastitis, although differences among countries exist. In cases of SCM in Scandinavian countries such as Sweden, Staph. epidermidis was more frequently isolated than Staph. chromogenes (Persson Waller et al., 2011; Nyman et al., 2018), whereas in Finland, Staph. simulans was the predominant species (Taponen et al., 2016).

The prevalence of the different NAS species isolated from bovine milk samples depends not only on the country or region but also varies with parity and stage of lactation of the animal. Heifers are more prone to IMI with NAS before or at the beginning of their lactation compared with multiparous cows (37.5 vs. $5.8 \%$ of the quarters, respectively; Taponen et al., 2007). Up to $45.5 \%$ of quarters might be NAS-infected at first calving (Oliver et al., 2003). In Sweden, 38, 26, and 36\% of 658 quarter milk samples that were positive for the 7 most common NAS species in that study were from first-parity, second-parity and older cows, respectively (Nyman et al., 2018). In heifers, Staph. chromogenes, Staph. xylosus, and Staph. simulans were more commonly found compared with third-parity or older cows (Thorberg et al., 2009; De Visscher et al., 2016; Condas et al., 2017a; Nyman et al., 2018), and the association with stage of lactation varies among the different NAS species (Condas et al., 2017a). In Flanders, Staph. chromogenes is also the predominant species both at parturition and in lactation in randomly selected heifers and older animals, followed by Staph. sciuri and Staph. cohnii at parturition (De Visscher et al., 2016) and by Staph. simulans, Staph. xylosus, Staph. epidermidis, and Staph. haemolyticus in lactation (Piessens et al., 2011; Supré et al., 2011).

Although the spontaneous cure rate of untreated subclinical NAS IMI in both primiparous and multiparous cows ranges between $39.5 \%$ (Taponen et al., 2006 ) and 64.5 to $72 \%$ (McDougall, 1998; Wilson et al., 1999), respectively, some NAS infections may persist for an entire lactation (Aarestrup and Jensen, 1997; Chaffer et al., 1999; Taponen et al., 2007). Up to 33\% of quarters were classified as having a persistent IMI with a NAS species in Sweden, and infection persisted in almost $40 \%$ of the quarters from which Staph. chromogenes was isolated (Nyman et al., 2018). Based on the ability to cause persistent infections and the genetic heterogeneity and clonality, some NAS species appear to be more adapted to the cow's mammary gland, such as Staph. chromogenes, Staph. epidermidis, Staph. simulans, and Staph. hyicus, and might hypothetically have a different effect on qSCC and qMY than other less cow-adapted NAS species (Taponen et al., 2008; Piessens et al., 2012; Fry et al., 2014; Nyman et al., 2018).

The effect of subclinical NAS IMI on SCC and milk yield (MY) has been studied almost exclusively at the heifer or cow level. Only a few studies have been conducted at the quarter level. Supré et al. (2011) called Staph. chromogenes, Staph. simulans, and Staph. xylosus the species "more relevant for udder health" with regard to the SCC of quarters being subclinically infected with these species, although no qMY data were available. The effect on qMY was elaborated by Tomazi et al. (2015) by milking quarters $(\mathrm{n}=82)$ individually using a bucket milking system to measure average qMY on sampling day. Subclinical IMI caused by Staph. chromogenes was found to have no effect on qMY, despite an increased qSCC, in a cohort of primiparous and multiparous cows at different stages of lactation. As these two studies either did not measure qMY or did not had a longitudinal follow-up, the question remains whether the "more relevant" species have a long-term impact on qSCC and qMY when quarters are infected in the first $18 \mathrm{~d}$ after calving.

This longitudinal study aimed at evaluating (1) the effect of subclinical IMI with all NAS species at the first sampling day (i.e., 1-4 DIM) on qSCC and qMY during the first $4 \mathrm{mo}$ of lactation in heifers (i.e., animals in first lactation) in 3 dairy herds milking with an automated milking system (AMS); and (2) the effect of transient, persistent, and new subclinical IMI with all NAS species or with Staph. chromogenes in the first $18 \mathrm{~d}$ after calving by including culture results available at 15 to 18 DIM, on qSCC and qMY during the first 4 mo of lactation. 


\section{MATERIALS AND METHODS}

\section{Herds, Animals, and Study Design}

The data in this study are part of the data set described in Valckenier et al. (2019). In short, the study was conducted from August 2013 until the end of October 2014. Eighty-two Holstein Friesian dairy heifers were included from 3 commercial dairy herds in the province of West Flanders (Belgium) equipped with an AMS. Herd owners were approached by the first author and asked whether they were willing to participate. None of the 3 herds treated their end-term heifers with antimicrobials before calving, and none of the herds participated in the local dairy herd improvement program.

The first author visited the herds 2 times per week, on Mondays and Thursdays, to perform quarter milk sampling of the heifers that had calved since the previous visit. Every heifer was thus sampled between 1 and 4 DIM. After the first sampling, all heifers were followed up until 127 to 130 DIM by collecting milk samples every $14 \mathrm{~d}$ another 9 times after the first sampling and recording all CM events.

During the sampling period, every heifer that calved was included in the study. No further inclusion or exclusion criteria were applied at the herd or heifer level. When a heifer was sold, culled, or died within the first 4 mo of lactation, it was not replaced by another animal. Nonfunctional quarters or quarters with CM before or at the first sampling were excluded because the aim of this study was to investigate the effects of IMI with NAS causing subclinical mastitis. For this reason, 2 quarters with $\mathrm{CM}$ and 2 nonfunctional quarters were excluded.

\section{Sampling, Quarter SCC, and Quarter MY}

Quarter milk samples were collected aseptically every $14 \mathrm{~d}$ on 10 occasions starting at 1 to 4 DIM according to the guidelines of the National Mastitis Council (Hogan et al., 1999). The time interval between the last milking before sampling and the sampling itself varied because all animals were milked voluntarily by the AMS. The qSCC of each sample was measured using a Direct Cell Counter DCC (DeLaval International AB, Tumba, Sweden) in the laboratory of the Mastitis and Milk Quality Research group at the Faculty of Veterinary Medicine of Ghent University (Merelbeke, Belgium). Milk samples taken within 1 to $4 \mathrm{~d}$ after calving (referred to as the first sampling day) and between 15 and 18 DIM (referred to as the second sampling day) were used for bacteriological culturing to determine the IMI status of each quarter.
Quarter milk production per milking was available through the herd management software of the AMS (DelPro, DeLaval International AB). The average daily qMY at the first sampling day (1-4 DIM) was calculated by summing the qMY per milking per day from calving up to d 7 after the sampling divided by the number of days. Subsequently, qMY was also available for an additional 9 consecutive 14-d periods (sampling days) by calculating the average daily qMY during each of these periods.

\section{Microbiology}

Standard bacteriological culture was performed as described elsewhere (Valckenier et al., 2019). Briefly, a 0.01-mL loop of milk was spread on a quadrant of an esculin blood agar plate and a MacConkey agar plate (Thermo Fisher Diagnostics N.V., Groot-Bijgaarden, Belgium) and aerobically incubated at $37^{\circ} \mathrm{C}$. The plates were phenotypically examined after $24 \mathrm{~h}$ and again after $48 \mathrm{~h}$. Identification of bacteria was done by Gram staining, inspection of colony morphology, and biochemical testing. Quarters were considered infected if one or more colonies were observed $(\geq 100 \mathrm{cfu} / \mathrm{mL})$ in the milk sample.

Staphylococcus aureus, esculin-positive and esculinnegative cocci, Trueperella pyogenes, Escherichia coli, Klebsiella spp., and other gram-negative bacteria were regarded as major pathogens. A quarter yielding a major pathogen and NAS, Bacillus spp., or Corynebacterium spp. was classified as infected with the major pathogen, whereas a quarter yielding 2 different major pathogens or 2 different minor pathogens was considered infected with the pathogen that had the highest count (cfu/ $\mathrm{mL}$ ). Samples yielding 3 or more different bacterial colony types were considered to be contaminated.

All isolates phenotypically identified as NAS during the trial were stored in Microbank vials (Pro-Lab diagnostics, Richmond Hill, ON, Canada) at $-80^{\circ} \mathrm{C}$ until the end of the sampling period. These isolates were identified at the species level using transfer RNA intergenic spacer PCR (tDNA-PCR) or, if no identification was obtained, sequencing of the $16 S$ rRNA or rpoB gene, as described by Supré et al. (2009).

\section{Clinical Mastitis and Culling}

Two heifers from herd 3 were culled after a severe case of CM between 57 and 74 DIM. One quarter from a heifer in herd 1 was immediately dried off after a CM case occurring between 85 and 102 DIM. Two heifers (herds 2 and 3) were sold between 85 and 102 DIM. The left hindquarter from a heifer in herd 3 was dried off at 85 DIM because of a teat end injury. The samples 
taken before these animals were culled or dried off were included in the analysis.

\section{Quarter-Level IMI}

From the 82 heifers included in this study, 324 quarters were eligible for sampling at the first sampling day (1-4 DIM). A quarter was defined as having an IMI at the first sampling day with a NAS species, Bacillus spp., Corynebacterium spp., Staph. aureus, Streptococcus spp., or gram-negative bacteria when the sample collected between 1 and 4 DIM contained $\geq 100 \mathrm{cfu} / \mathrm{mL}$ of the specific bacteria (Dohoo et al., 2011).

Combining the culture results from the first and second sampling days allowed us to define quarters as having a transient IMI (tIMI) with a NAS species if the NAS species isolated at the first sampling day was not recovered at the second sampling day. A persistent IMI (pIMI) was defined when the quarter was infected with the same NAS species at the second sampling day. Quarters that were noninfected at the first sampling day and infected with a NAS species at the second sampling day were defined as having a new IMI (nIMI). A quarter was considered to be noninfected on the first and second sampling days if both milk samples were culture-negative for any pathogen.

Overall, 648 samples were collected from 324 quarters from 82 heifers (Table 1). Based on standard bacteriological culturing, $220(67.9 \%)$ quarters were noninfected at the first sampling day (1-4 DIM), whereas $245(75.6 \%)$ were noninfected at the second sampling day. Overall, NAS were the most prevalent group of bacteria with 21.0 and $10.5 \%$ of quarters being infected at the first and second sampling days, respectively.
To investigate the effect of IMI at the first sampling day with Staph. chromogenes or other NAS species, only quarters that were noninfected or infected with either NAS or a major pathogen at the first sampling day (1-4 DIM) were retained for further analysis. If the NAS isolate could not be identified to the species level (e.g., by contamination of the Microbank vial or no growth after culturing of the sample), the corresponding quarter $(\mathrm{n}=18)$ was omitted from the analysis.

Only quarters considered to have a tIMI, pIMI, or nIMI with a specific NAS species or that were noninfected at the first and second sampling days were retained to evaluate the effect of these infections at the qSCC and daily qMY during the first 4 mo of lactation.

\section{Statistical Analyses}

All data were entered in an electronic spreadsheet program (Excel 2016, Microsoft Corp., Redmond, WA) and checked for unlikely values.

Common Features of the Statistical Models. The associations between quarter IMI (qIMI) status, sampling day qSCC, and sampling day qMY (outcome variables) throughout the first 4 mo of lactation, respectively, were determined fitting 2 separate linear mixed models with herd (forced into the model as fixed effect), heifer (random effect), and quarter (random effect) to correct for potential clustering of heifers within herds, for clustering of quarters within heifer, and for clustering of observations (10 repeated samplings, including that at 1-4 DIM) within quarters, respectively. A natural logarithmic transformation of the qSCC (qLnSCC) was performed to obtain a normal distribution. The models included sampling day (10 levels: 1

Table 1. Overview of bacteriological culture results from samples $(\mathrm{n}=324)$ collected at the first (1-4 DIM) and second (15-18 DIM) sampling day

\begin{tabular}{|c|c|c|c|c|c|c|}
\hline Bacteriological culture result & \multicolumn{3}{|c|}{ First sampling day } & \multicolumn{3}{|c|}{ Second sampling day } \\
\hline Corynebacterium spp. & 6 & 1.9 & 6.7 & 6 & 1.9 & 9.4 \\
\hline Bacillus spp. & 6 & 1.9 & 6.7 & 16 & 4.9 & 25.0 \\
\hline Escherichia coli $^{3}$ & 5 & 1.5 & 5.6 & - & - & - \\
\hline $\mathrm{NAS}^{4}$ & 68 & 21.0 & 76.4 & 34 & 10.5 & 53.1 \\
\hline Contaminated $^{5}$ & 15 & 4.6 & - & 15 & 4.6 & - \\
\hline
\end{tabular}

\footnotetext{
${ }^{1}$ Number of samples.

${ }^{2}$ Resulting in the IMI status "noninfected."

${ }^{3}$ Resulting in the IMI status "infected with major pathogen."

${ }^{4}$ Resulting in the IMI status "infected with NAS."

${ }^{5}$ More than 2 bacterial colony types.
} 
to 10) and quarter position (2 levels: front vs. hind) as categorical predictor variables.

The initial linear mixed model with qSCC as outcome variable [SCC model] was

$$
\begin{aligned}
\mathrm{qLnSCC}_{i j k l}=\beta_{0} & +\beta_{1} \mathrm{qIMI}_{j k l}+\beta_{2} \text { Quarter position }_{j k l} \\
+\beta_{3} \operatorname{Herd}_{k l} & +\beta_{4} \text { Sampling day }_{i j k l}+\mu_{\text {Heifer_kl(j) }} \\
& +\mu_{\text {Quarter_jkl(i) }}+\mathrm{e}_{i j k l},
\end{aligned}
$$

where $\mathrm{qLnSCC}_{i j k l}$ is the natural logarithm of SCC for the $i$ th sample $(i=1-10)$ of the $j$ th quarter $(j=1-4)$ of the $k$ th heifer $(k=1-82)$ from the $l$ th herd $(l=$ $1-3) ; \beta_{0}$ is the intercept (overall mean); $\beta_{1}$ to $\beta_{4}$ are the regression coefficients of the fixed effects: quarter IMI status, quarter position, herd, and sampling day, respectively; $\mu_{\text {Heifer } \_k l(j)}$ is the random effect of the heifer $k$ from herd $l$ to correct for clustering of quarters within

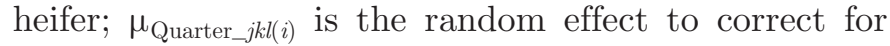
within-quarter correlation of subsequent biweekly sampling days $i$ (repeated statement) for quarter $j$ of heifer $k$ from herd $l$; and $\mathrm{e}_{i j k l}$ is the random error term.

The initial linear mixed model with daily qMY as outcome variable [MY model] was

$$
\begin{gathered}
\mathrm{qMY}_{i j k l}=\beta_{0}+\beta_{1} \mathrm{qIMI}_{j k l}+\beta_{2} \text { Quarter position }_{j k l} \\
+\beta_{3} \operatorname{Herd}_{k l}+\beta_{4} \text { Sampling day }_{i j k l}+\beta_{5} \mathrm{qLnSCC}_{i j k l} \\
+\mu_{\text {Heifer_kl(j) }}+\mu_{\text {Quarter_jkl(i) }}+\mathrm{e}_{i j k l},
\end{gathered}
$$

where qMY is the quarter milk yield for the $i$ th sample $(i=1-10)$ of the $j$ th quarter $(j=1-4)$ of the $k$ th heifer $(k=1-82)$ from the $l$ th herd $(l=1-3) ; \beta_{0}$ is the intercept (overall mean); $\beta_{1}$ to $\beta_{5}$ are the regression coefficients of the fixed effects: quarter IMI status, quarter position, herd, sampling day, and the natural logarithm of the qSCC at sampling day, respectively; $\mu_{\mathrm{Heifer} \_k l(j)}$ is the random effect of the heifer $k$ from herd $l$ to correct for clustering of quarters within heifer; $\mu_{\text {Quarter_jkl(i) }}$ is the random effect to correct for within-quarter correlation of subsequent biweekly sampling days $i$ (repeated statement) for quarter $j$ of heifer $k$ from herd $l$; and $\mathrm{e}_{i j k l}$ is the random error term.

Linear mixed models were fit in SAS (PROC MIXED; version 9.4; SAS Institute Inc., Cary, NC). For all linear mixed models, the goodness-of-fit measures included $-2 \times \log$-likelihood, the Akaike information criterion, and the Bayesian information criterion. Residuals were evaluated graphically and plotted against the predicted values. A Bonferroni correction was used to correct for multiple comparisons. Significance was assessed at $P \leq$ 0.05 . Nonsignificant variables $(P>0.05)$ were omitted using a backward stepwise approach. In all linear mixed models, a first-order autoregressive correlation structure was used to account for the clustering of repeated sampling days within a quarter.

To evaluate the proportion of variance in $q \mathrm{LnSCC}$ and qMY occurring at the heifer, quarter, and sampling day levels, 3-level null models (intercept only) were fit. The total variance was estimated as follows:

$$
\operatorname{Var}\left(\mathbf{Z}_{i j k}\right)=\operatorname{var}\left(\mu_{\text {Heifer }(k)}\right)+\operatorname{var}\left(\mu_{\text {Quarter }(j k)}\right)+\operatorname{var}\left(\mu_{\text {Sample }(i j k)}\right),
$$

where $\mathbf{Z}_{i j k}$ is the qLnSCC or qMY for the $i$ th sample $(i$ $=1-10)$ of the $j$ th quarter $(j=1-4)$ of the $k$ th heifer $(k=1-82) ; \operatorname{var}\left(\mu_{\text {Heifer }(k)}\right)$ is the variance occurring at the heifer level, $\operatorname{var}\left(\mu_{\text {Quarter }(j k)}\right)$ is the variance occurring at the quarter level, and $\operatorname{var}\left(\mu_{\text {Sample(ijk) }}\right)$ is the variance occurring at the sampling day level.

Effect of IMI with Staph. chromogenes Versus All Other NAS at the First Sampling Day on $q S C C$ and $q M Y$. Because the number of observations was too small to analyze individual species other than Staph. chromogenes, these were included as a group (named "all other NAS species") in the statistical analyses. Associations between quarter IMI status at the first sampling day (categorical predictor variable of main interest with 4 levels: noninfected, infected with S. chromogenes, infected with all other NAS species, or infected with a major pathogen) and the outcome variable sampling day $\mathrm{qSCC}$ and sampling day $\mathrm{qMY}$ throughout the first 4 mo of lactation, respectively, were determined fitting 2 separate linear mixed models.

Effect of tIMI, pIMI, or nIMI with NAS on $q S C C$ and $q M Y$. The associations between qIMI status based on the first 2 sampling days (categorical predictor variable of main interest with 4 levels: noninfected at the first and second sampling days, transient infection with a NAS species, persistent infection with a NAS species, or new infection with a NAS species) and sampling day qSCC and sampling day qMY (2 separate outcome variables) throughout the first 4 mo of lactation, respectively, were determined fitting 2 separate linear mixed models.

Effect of tIMI, pIMI, or nIMI with Staph. chromogenes on $q S C C$ and $q M Y$. The association between qIMI status based on the first 2 sampling days (categorical predictor variable of main interest with 4 levels: noninfected at the first and second sampling days, transient infection with Staph. chromogenes, persistent infection with Staph. chromogenes, or new infection with Staph. chromogenes) and either sampling day qSCC or sampling day qMY (outcome variables) throughout the first 4 mo of lactation, respectively, was determined fitting 2 separate linear mixed models. 


\section{RESULTS}

\section{IMI After Calving}

Of the 220 quarters that were noninfected at the first sampling day, 179 (81.4\%) remained noninfected, $15(6.8 \%)$ had a nIMI with NAS, and $5(2.3 \%)$ had a major pathogen IMI at the second sampling day (Table 2). Forty-eight of the $68(70.6 \%)$ quarters that were initially infected with NAS at the first sampling day were no longer infected with NAS at the second sampling day. None of the 68 NAS-infected quarters at the first sampling day became infected with a major pathogen at the second sampling day. Sixteen (23.5\%) quarters infected with NAS at the first sampling day were still NAS-infected at the second sampling day, 9 of which were infected with the same NAS species at both sampling days and thus considered to have a pIMI. The IMI status of $4(5.9 \%)$ quarters infected with NAS at the first sampling day could not be determined at the second sampling day because of contamination of the milk samples. In 45 quarters that were infected with a NAS species at the first sampling day, the same NAS species was no longer present at the second sampling day (i.e., tIMI).

\section{NAS Species Distribution}

In total, 102 isolates were phenotypically identified as NAS and further identified to the species level. Staphylococcus chromogenes was the most prevalent species at the first sampling day (29.4\% of 68 isolates), followed by Staph. xylosus, Staph. vitulinus, and Staph. sciuri (each $8.8 \%$ ). At the second sampling day, Staph. chromogenes was still the predominant species $(52.9 \%$ of 34 isolates), followed by Staph. xylosus (11.8\%; Figure 1). One isolate, initially phenotypically misclassified as NAS, was identified as Staph. aureus. Eighteen of the isolates (17.7\%) - 14 obtained at the first sampling day and 4 at the second sampling day - could not be identified to the species level because of contamination of the Microbank vial or could not be cultured from the Microbank, and these quarters were omitted for further statistical analyses.

\section{Effect of IMI with Staph. chromogenes Versus All Other NAS at the First Sampling Day on qSCC and $q M Y$}

The variable quarter position was not significantly associated with qLnSCC in the initial model and omitted from the final model. Quarters infected with Staph. chromogenes at the first sampling day $(\mathrm{n}=20 ; 1-4$ DIM) had a significantly higher sampling day qLnSCC than noninfected quarters $(\mathrm{n}=220 ; 144,000$ cells $/ \mathrm{mL}$ vs. 67,000 cells $/ \mathrm{mL}$, respectively; $P<0.001$; Table 3 ), and a sampling day qLnSCC that did not differ from quarters infected with a major pathogen $(\mathrm{n}=9$; 162,000 cells $/ \mathrm{mL} ; P=0.99$ ). Interestingly, we found no difference between SCC in quarters infected with Staph. chromogenes and quarters infected with a major pathogen $(P=0.99)$, and between quarters infected with any other NAS species than Staph. chromogenes ( $\mathrm{n}=34$ ) at the first sampling day and noninfected quarters $(P=0.93)$.

Table 2. Overview of the quarter-level IMI (qIMI) status at the first sampling day (1-4 DIM) and the associated qIMI at the second sampling day (15-18 DIM) in 297 quarters from 82 dairy heifers in 3 herds ${ }^{1}$

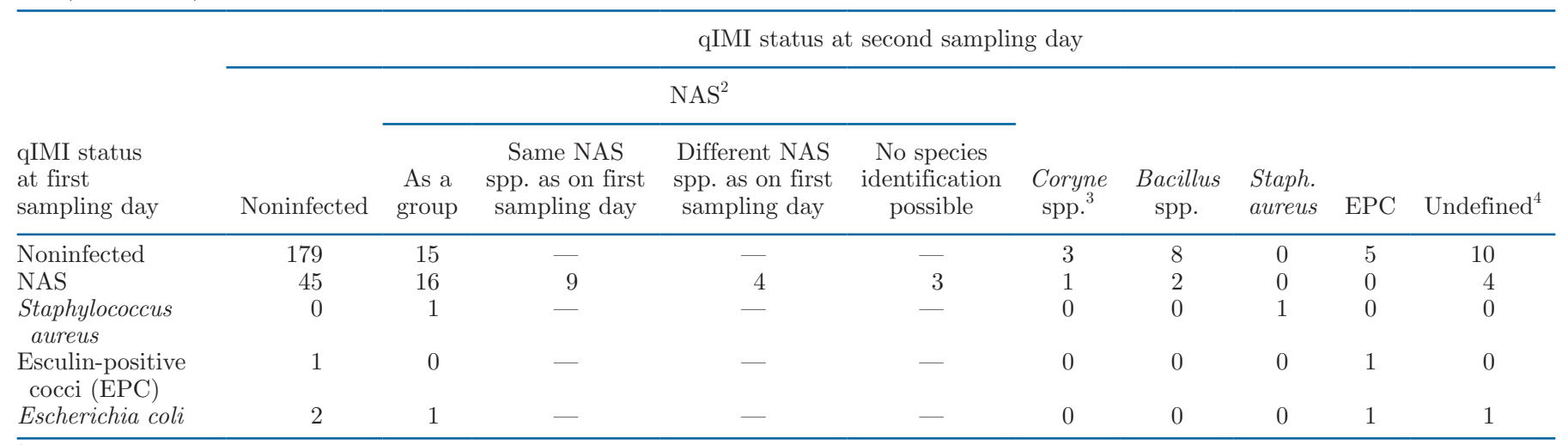

${ }^{1}$ Only quarters that were noninfected $(\mathrm{n}=220)$, NAS-infected $(\mathrm{n}=68)$, and major pathogen-infected $($ Staph. aureus-infected, $\mathrm{n}=2$; EPCinfected, $\mathrm{n}=2 ; E$. coli-infected, $\mathrm{n}=5)$ at the first sampling day, and thus relevant for further statistical analysis in the scope of this study, are shown.

${ }^{2}$ Phenotypically identified as NAS.

${ }^{3}$ Corynebacterium spp.

${ }^{4}$ Contaminated samples (more than 2 phenotypically different colony types). 
Table 3. Final linear mixed regression model describing the association between the natural log-transformed quarter milk SCC (qLnSCC; outcome variable) during the first 4 mo of lactation and quarter-level IMI (qIMI) status at the first sampling day (1-4 DIM; main predictor of interest) of 283 quarters from 82 dairy heifers in 3 herds

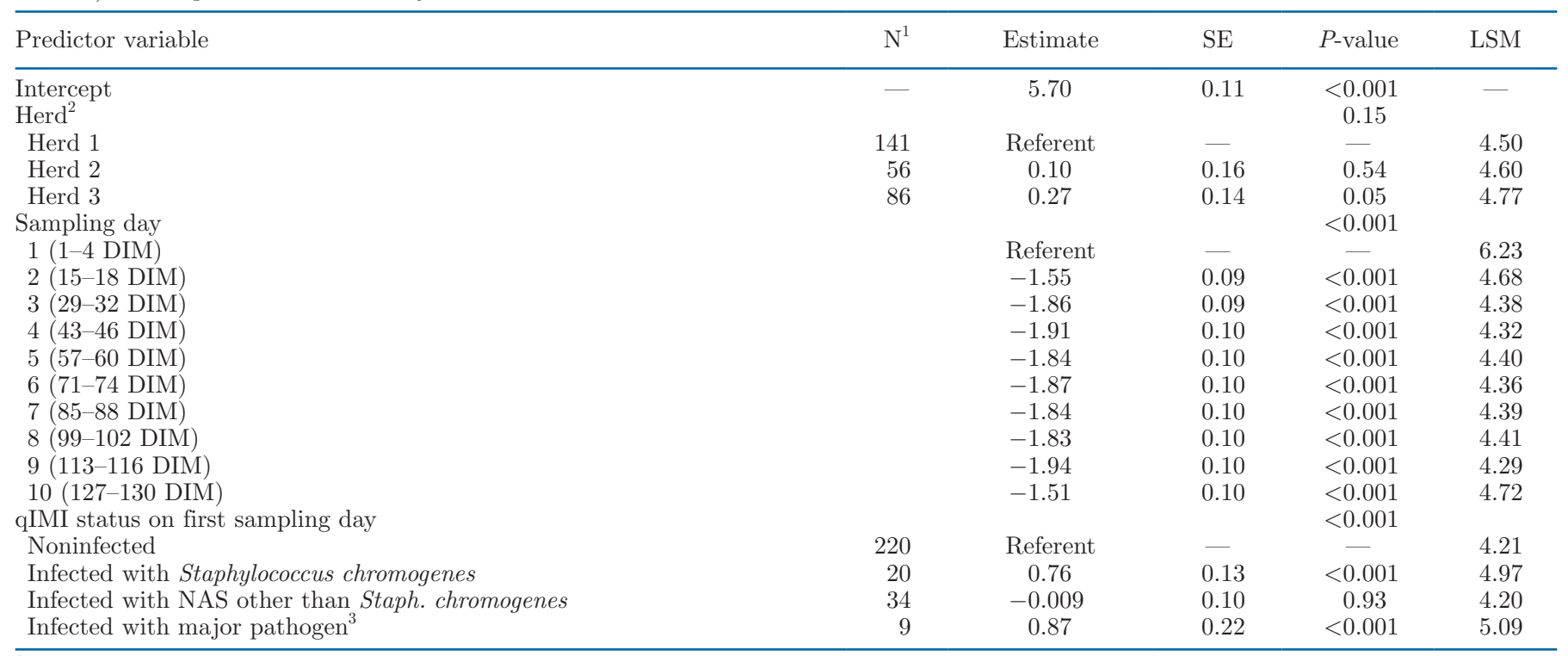

${ }^{1}$ Number of quarters.

${ }^{2}$ Herd was forced in the model to correct for potential clustering of heifers within herds.

${ }^{3}$ Escherichia coli, Staphylococcus aureus, esculin-positive cocci. Quarters for whom the NAS isolate could not be identified to the species level $(\mathrm{n}=14)$ were omitted from the analysis.

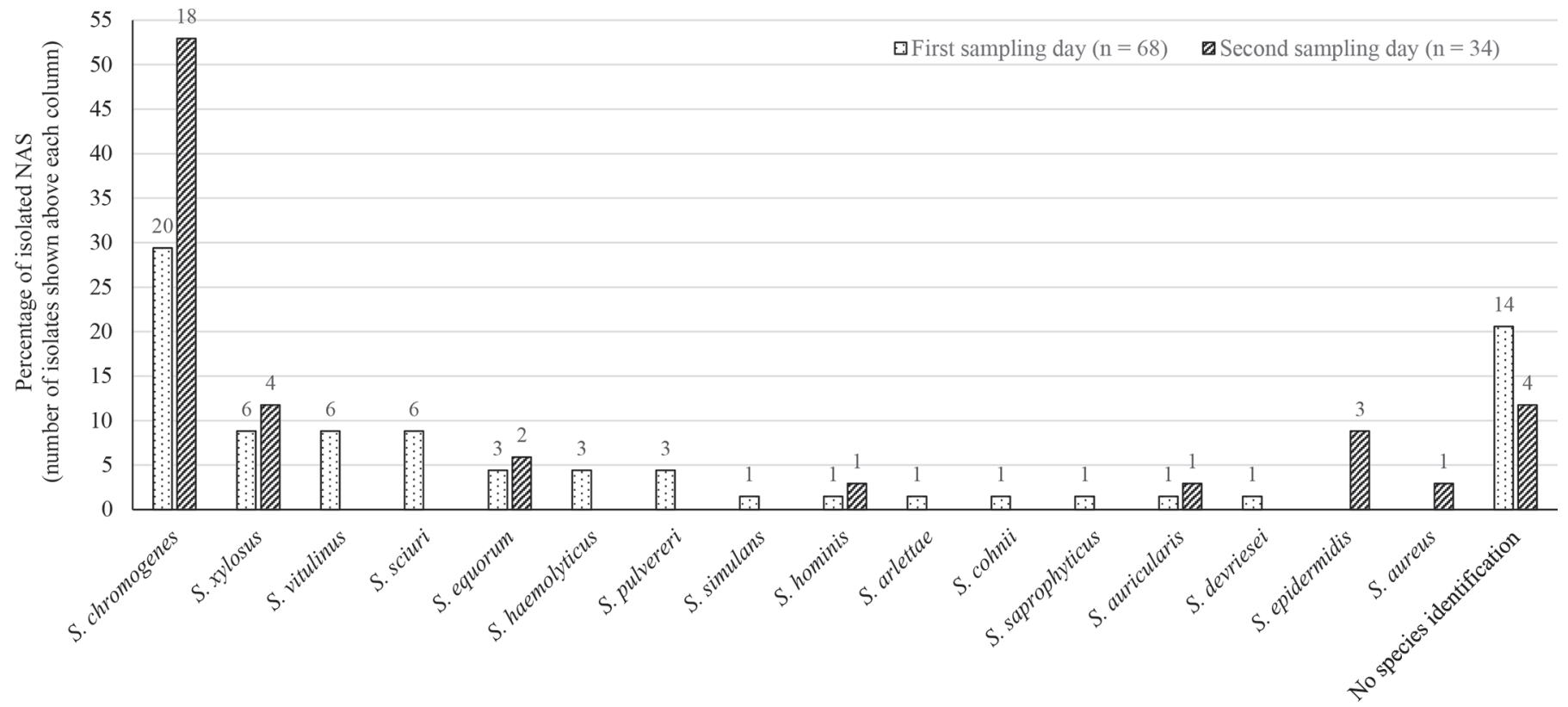

Species identification

Figure 1. Staphylococcus species identification and relative distribution of the isolates phenotypically identified as NAS at the first (1-4 DIM) and second (15-18 DIM) sampling day (quarters from which the isolates could not be identified to the species level were omitted for further statistical analysis). 
Table 4. Final linear mixed regression model describing the association between the daily quarter milk yield (outcome variable) during the first 4 mo of lactation and quarter-level IMI (qIMI) status at the first sampling day (1-4 DIM; main predictor of interest) of 283 quarters from 82 dairy heifers in 3 herds

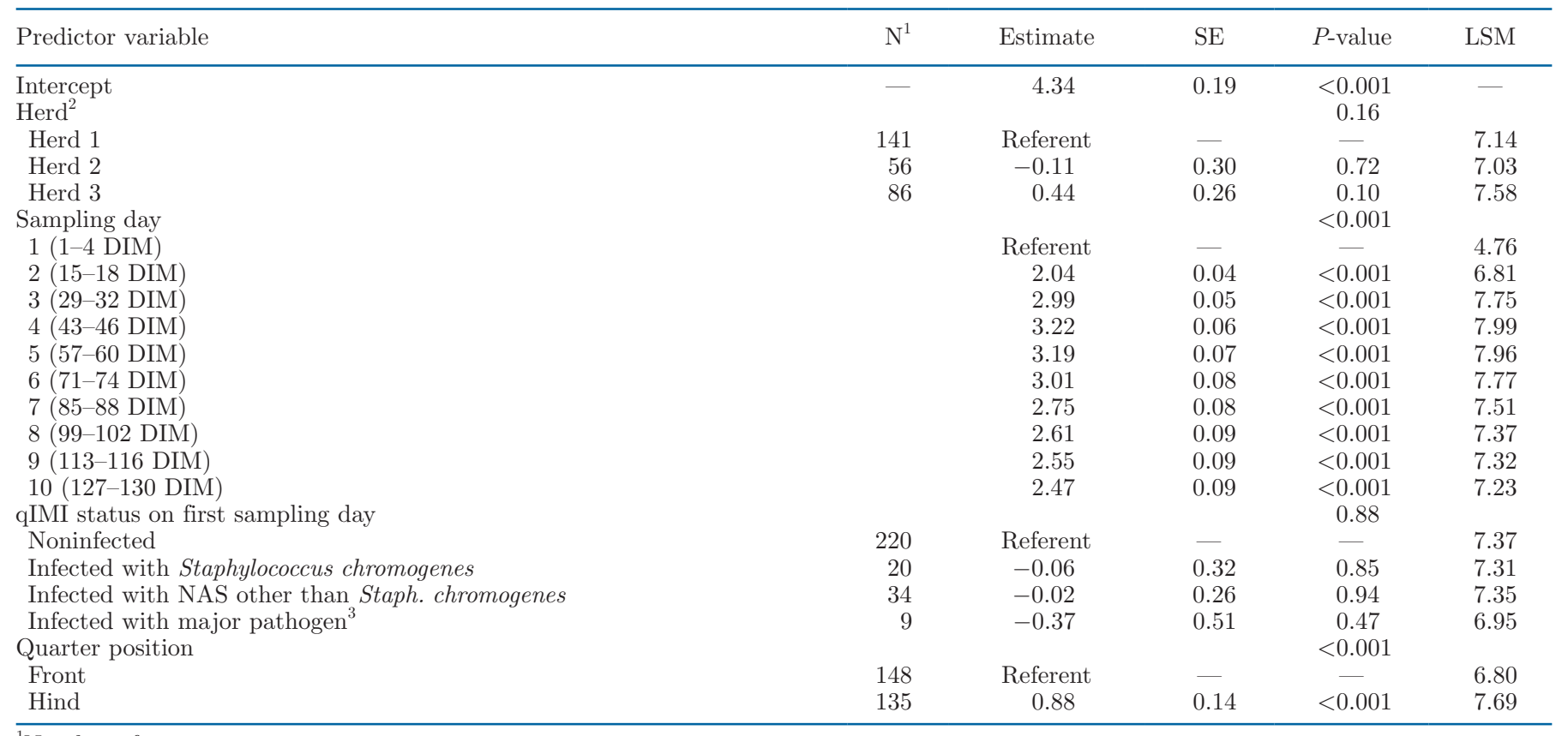

\footnotetext{
${ }^{1}$ Number of quarters.

${ }^{2}$ Herd was forced in the model to correct for potential clustering of heifers within herds.

${ }^{3}$ Escherichia coli, Staphylococcus aureus, esculin-positive cocci.
}

The variable qLnSCC was not significantly associated with qMY in the initial model and was omitted from the final model. The qMY over the first 4 mo of lactation did not differ between noninfected quarters $(\mathrm{n}=220 ; 7.37 \mathrm{~kg} / \mathrm{d})$ and quarters infected with Staph. chromogenes $(\mathrm{n}=20 ; 7.31 \mathrm{~kg} / \mathrm{d} ; P=0.85)$ or with any other NAS species $(\mathrm{n}=34 ; 7.35 \mathrm{~kg} / \mathrm{d} ; P=0.94$; Table 4). Hind quarters produced, on average, $0.89 \mathrm{~kg} / \mathrm{d}$ more than front quarters $(P<0.001)$. Noninfected quarters produced $0.42 \mathrm{~kg} / \mathrm{d}$ more in the first 4 mo of lactation compared with quarters infected with a major pathogen $(\mathrm{n}=9)$ at the first sampling day $(P=0.47)$.

For the LnSCC model, only 11.6 and $9.4 \%$ of the variation resided at the heifer and quarter level, respectively, while $79.0 \%$ of the total variation occurred at the level of the repeated samplings (sampling day). For the MY model, the variation was the smallest at the heifer level $(6.0 \%)$ and slightly larger at the quarter level $(16.6 \%)$. The largest proportion of the variation resided at the level of the repeated samplings (77.4\%).

\section{Effect of tIMI, pIMI, or nIMI with All NAS Species on qSCC and $q M Y$}

Besides the 8 pIMI caused by Staph. chromogenes, only Staph. xylosus was responsible for 1 other pIMI with NAS at the first sampling day. Species other than Staph. chromogenes were the cause of more tIMI and nIMI cases. The evolution of mean qSCC and mean daily qMY over the first 4 mo of lactation for quarters having a tIMI, pIMI, and nIMI with NAS at the first and second sampling day are depicted in Figure 2.

The variable quarter position was not significantly associated with qLnSCC in the initial model and omitted from the final model. The SCC in quarters having a tIMI with a NAS species $(\mathrm{n}=45 ; 73,000$ cells $/ \mathrm{mL})$ was not significantly higher than that of noninfected quarters $(\mathrm{n}=177 ; 63,000$ cells $/ \mathrm{mL} ; P=0.10$; Table $5)$. Quarters with a pIMI with a NAS species $(\mathrm{n}=9)$ had the highest SCC $(226,000$ cells $/ \mathrm{mL} ; P<0.001)$, followed by quarters with a nIMI with a NAS species $(\mathrm{n}=15)$ at the second sampling day $(119,000$ cells $/ \mathrm{mL}$; $P<0.001)$.

The variable $\mathrm{qLnSCC}$ was not significantly associated with qMY in the initial model and omitted from the final model. The qIMI status at the first and second sampling day was not significantly associated with the daily qMY in the first 4 mo after calving (Table 6). Noninfected quarters $(\mathrm{n}=177)$ and quarters with a tIMI with NAS $(\mathrm{n}=45)$ had the same daily qMY (7.37 vs. $7.37 \mathrm{~kg} / \mathrm{d} ; P=0.99)$, whereas $\mathrm{qMY}$ was lower in quarters with a pIMI $(\mathrm{n}=9 ; 7.33 \mathrm{~kg} / \mathrm{d} ; P=0.93)$ and 
higher in quarters with a nIMI $(\mathrm{n}=15 ; 7.72 \mathrm{~kg} / \mathrm{d} ; P$ $=0.35)$ infection.

\section{Effect of tIMI, pIMI, or nIMI with Staph. chromogenes on qSCC and $q M Y$}

Quarter position was not significantly associated with qLnSCC in the initial model and was omitted from the final model. Transient $(\mathrm{n}=12 ; 93,000$ cells/ $\mathrm{mL})$, persistent $(\mathrm{n}=8 ; 340,000$ cells $/ \mathrm{mL})$, and new (n $=5 ; 302,000$ cells $/ \mathrm{mL}$ ) IMI with Staph. chromogenes resulted in a significantly higher sampling day qLnSCC in affected quarters compared with noninfected quarters (n $=177 ; 63,000$ cells $/ \mathrm{mL} ; P=0.01, P<0.001$, and $P<0.001$, respectively; Table 7$)$. The SCC in quarters with a nIMI with Staph. chromogenes was not different compared with that of quarters with pIMI $(P=0.99)$.

The variable qLnSCC was not significantly associated with qMY in the initial model and omitted from the final model. Quarters that were noninfected at the first and second sampling days $(\mathrm{n}=177)$ had an average daily MY of $7.38 \mathrm{~kg}$ in the first 4 mo of lactation (Table 8). Persistent IMI with Staph. chromogenes (n $=8 ; 7.11 \mathrm{~kg} / \mathrm{d}$ ) had no significant effect on daily qMY $(P=0.60)$. The daily qMY in quarters newly infected with Staph. chromogenes $(\mathrm{n}=5 ; 7.92 \mathrm{~kg} / \mathrm{d})$ was not significantly different from that of noninfected quarters $(P=0.41)$ during the first 4 mo of lactation.

\section{DISCUSSION}

Most studies have reported that IMI caused by NAS results in a higher SCC compared with that in noninfected quarters, whereas there is more ambiguity about the effect of NAS IMI on MY. Some studies have found a negative association between NAS IMI and MY (Timms and Schultz, 1987; Gröhn et al., 2004), whereas others found no association (Tomazi et al., 2015; Heik-

$$
\begin{array}{ll}
\longrightarrow \times \text { Noninfected }(\mathrm{n}=177)(\mathrm{SCC}) & \longrightarrow \text { Transient IMI }(\mathrm{n}=45)(\mathrm{SCC})-\text { Persistent IMI }(\mathrm{n}=9)(\mathrm{SCC}) \\
\longrightarrow \text { New IMI }(\mathrm{n}=15)(\mathrm{SCC}) & -\times \text { Noninfected }(\mathrm{n}=177)(\mathrm{MY}) \quad-\text { Transient IMI }(\mathrm{n}=45)(\mathrm{MY}) \\
-\triangle \text { Persistent IMI }(\mathrm{n}=9)(\mathrm{MY}) & -\sim \text { New IMI }(\mathrm{n}=15)(\mathrm{MY})
\end{array}
$$

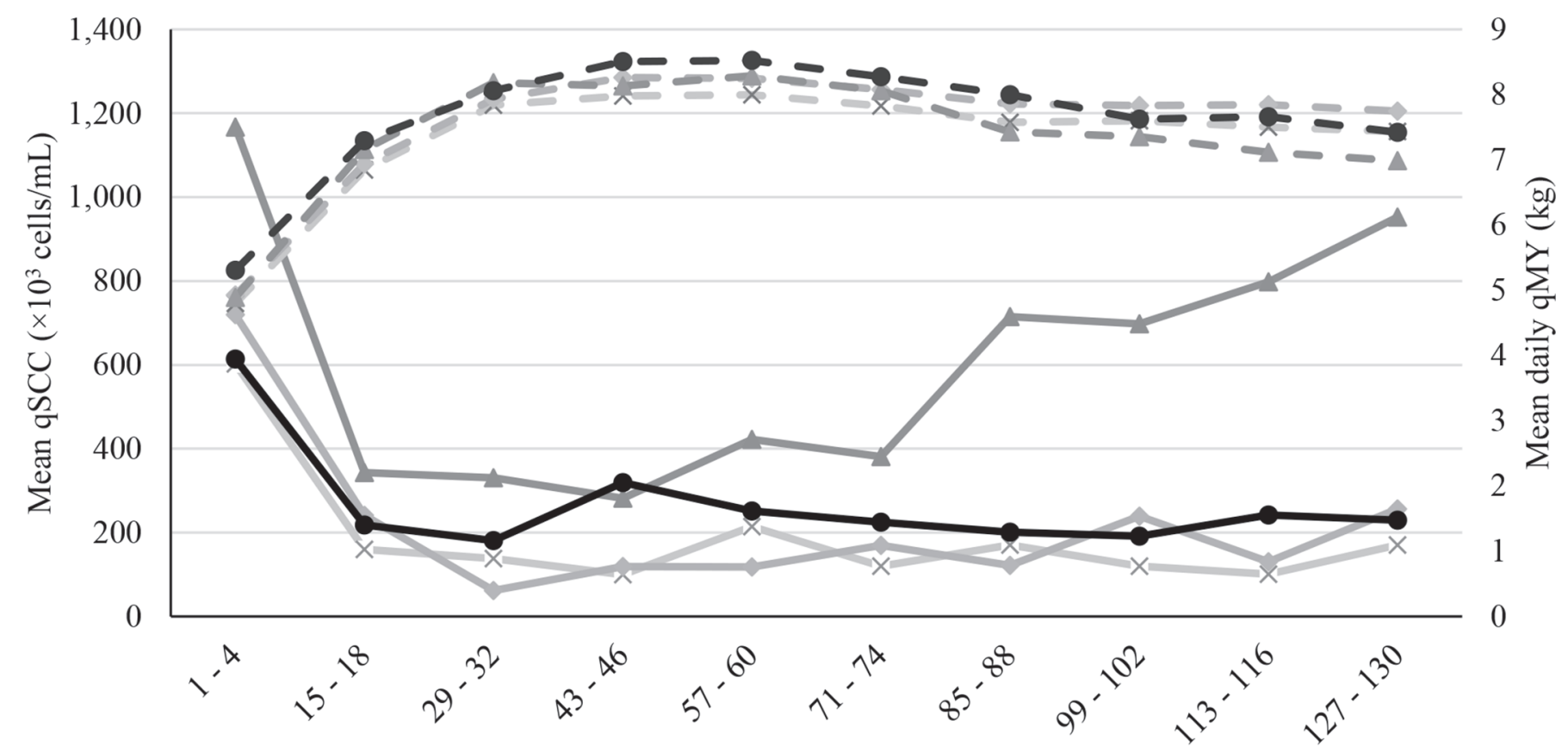

DIM

Figure 2. Evolution of the mean quarter milk SCC (qSCC) and mean daily quarter milk yield (qMY) during the first 4 mo of lactation for quarters having a transient, persistent, or new quarter-level IMI (qIMI) with NAS on the first (1-4 DIM) and second (15-18 DIM) sampling day after calving. Noninfected was defined as a culture-negative test result at the first and second sampling day; transient IMI was defined as a culture-positive test result for an NAS species at the first sampling day and a culture-negative test result for the same NAS species at the second sampling day; persistent IMI was defined as a culture-positive test result for the same NAS species on the first and second sampling days; new IMI was defined as a culture-negative test result at the first sampling day and a culture-positive test result at the second sampling day. 
Table 5. Final linear mixed regression model describing the association between the natural log-transformed quarter milk SCC (qLnSCC; outcome variable) during the first 4 mo of lactation and transient, persistent, and new quarter-level IMI (qIMI) with any NAS species at the first (1-4 DIM) and second (15-18 DIM) sampling day after calving (main predictor of interest) of 246 quarters from 80 dairy heifers in 3 herds

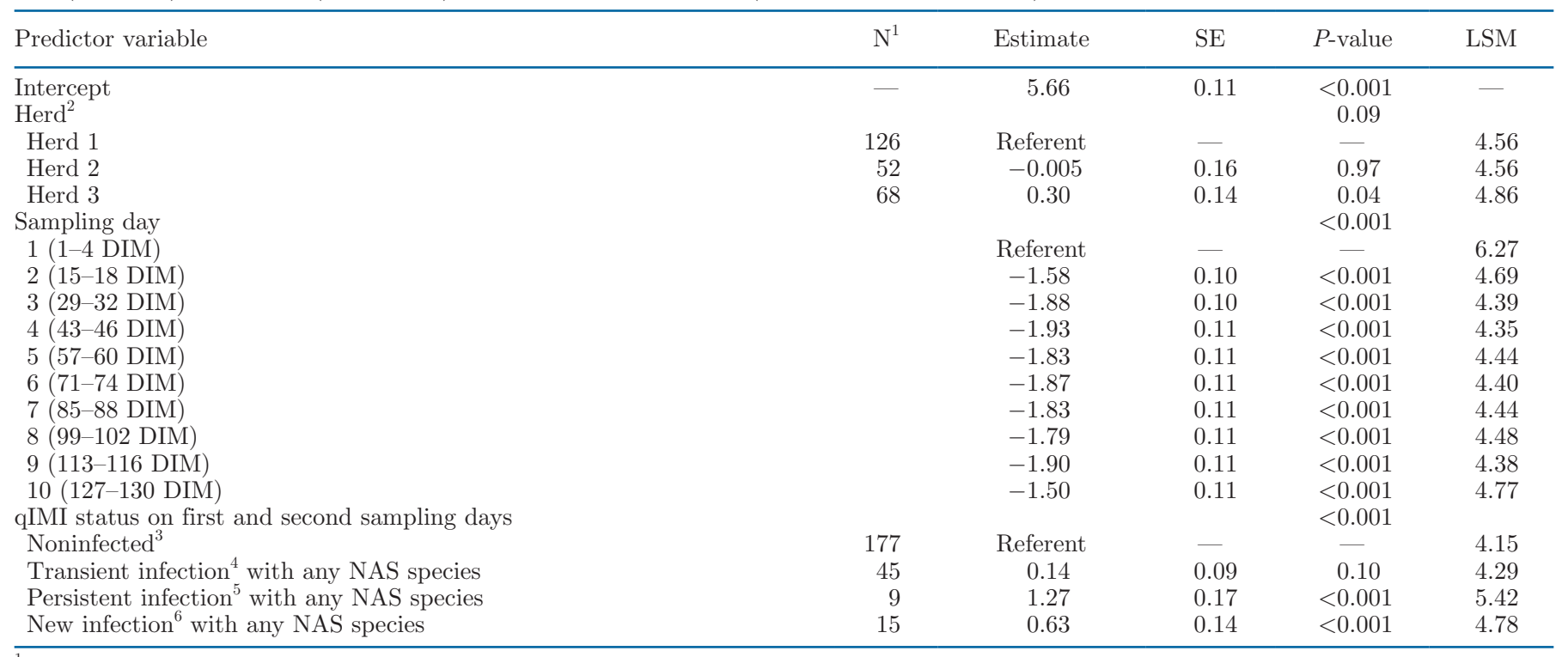

${ }^{1}$ Number of quarters.

${ }^{2}$ Herd was forced in the model to correct for potential clustering of heifers within herds.

${ }^{3}$ Based on a culture-negative test result on the first and second sampling days.

${ }^{4}$ Based on a culture-positive test result for a bacterial species at the first sampling day and a culture-negative test result for the same bacterial species at the second sampling day.

${ }^{5}$ Based on a culture-positive test result for the same bacterial species on the first and second sampling days.

${ }^{6}$ Based on a culture-negative test result at the first sampling day and a culture-positive test result at the second sampling day.

kilä et al., 2018) or even a positive association (Compton et al., 2007; Schukken et al., 2009; Piepers et al., 2010, 2013). These conflicting results can be explained at least in part by the fact that, in many studies, NAS were considered a homogeneous group of different species, whereas enough evidence now exists to show that the different NAS species differ in pathogenicity, virulence, ecology and epidemiology (reviewed by Vanderhaeghen et al., 2014, 2015). In our previous study, we investigated the effect of IMI with NAS, as a group, in the first $4 \mathrm{~d}$ after calving on the qSCC and qMY in the first 4 mo of lactation in dairy heifers (Valckenier et al., 2019). Non-aureus staphylococcus IMI at 1 to 4 DIM was found to cause a slight increase in qSCC $(89,000$ cells $/ \mathrm{mL}$ ) during the first 130 DIM compared with that in noninfected quarters $(66,000$ cells $/ \mathrm{mL})$, whereas it was not associated with daily qMY. The aim of the present study was to provide a more in-depth analysis by studying species-specific relationships with qSCC and qMY. Furthermore, rather than focusing only on IMI at the first sampling day, IMI status at both 1 to 4 DIM and 15 to 18 DIM were considered, allowing us to study the effects of new, transient, and persistent IMI with NAS, and Staph. chromogenes in particular, on milk production and udder health during the first 4 mo of lactation.

As expected (Fox, 2009; De Vliegher et al., 2012), NAS were the most prevalent cause of IMI in fresh heifers in our study, with 68 of the 324 quarters being NASinfected at the first sampling day. Also not surprisingly, Staph. chromogenes was the most prevalent species (20 out of 68 quarters), followed by Staph. xylosus, Staph. vitulinus, and Staph. sciuri, each of which were isolated from 6 different quarters. By way of comparison, in the study of De Visscher et al. (2016), Staph. chromogenes accounted for $41.4 \%$ of NAS species isolated from heifers and multiparous cows within $4 \mathrm{~d}$ after parturition. Up to 47.5 and $74.1 \%$ of the NAS isolates were identified as Staph. chromogenes in the studies of Fry et al. (2014) and Tomazi et al. (2015), respectively.

The effect of NAS IMI at the first sampling day on qSCC in later lactation depends on the NAS species, whether the infections persists for at least $2 \mathrm{wk}$, and the time after calving when infection occurs (1-4 DIM vs. 15-18 DIM). The qSCC in quarters having a tIMI with NAS at the first sampling day did not differ significantly from that of noninfected quarters when all isolated NAS species were taken into account. 
Table 6. Final linear mixed regression model describing the association between the daily quarter milk yield (outcome variable) during the first 4 mo of lactation and transient, persistent, and new quarter-level IMI (qIMI) with any NAS species at the first (1-4 DIM) and second (15-18 DIM) sampling day after calving (main predictor of interest) of 246 quarters from 80 dairy heifers in 3 herds

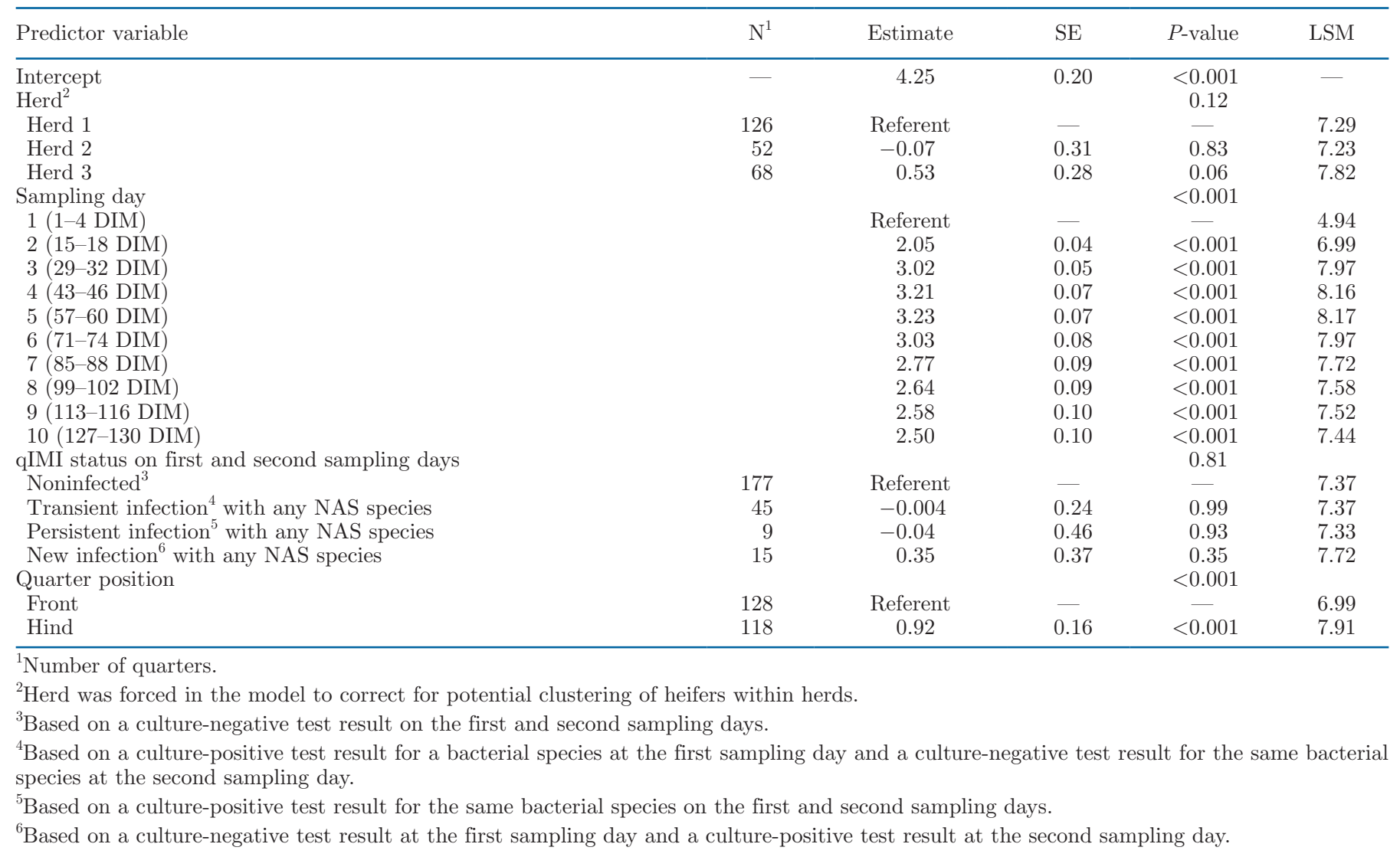

Both pIMI and nIMI resulted in a significantly higher qSCC in the first 130 DIM compared with that of noninfected quarters or quarters having a tIMI with NAS. This is in contrast to the results of Thorberg et al. (2009), where no difference between nonpersistent and persistent subclinical IMI caused by NAS was observed, although this study was based on the composite SCC measured at only 2 milk recordings. When only Staph. chromogenes was considered, the persistence of IMI and the time of infection in the first $18 \mathrm{~d}$ after calving appeared less decisive because tIMI, pIMI, and nIMI resulted in a significantly higher qSCC compared with that of noninfected quarters, although pIMI and nIMI also resulted in the highest qSCC in affected quarters. Previous studies at the quarter level (Fry et al., 2014; Condas et al., 2017b) or a combination of cow and quarter level (Nyman et al., 2018) also showed that Staph. chromogenes was among the NAS species that resulted in a significantly higher SCC and was more prevalent in high- than in low-SCC quarters. We acknowledge that strain typing of the NAS isolates cultured at different time points from the same quarter is imperative to consider IMI a persistent infection. However, Fry et al. (2014) demonstrated that, if a NAS species was isolated multiple times from the same quarter, in $91.4 \%$ of these quarters the isolates had the same pulsed-field gel electrophoresis banding pattern. This supports our approach to consider the infection as persistent if the same NAS species is isolated from 2 successive samplings.

In contrast to the effect of IMI with NAS on qSCC, NAS IMI at the first sampling day or 2 wk later and average daily qMY in the first 4 mo of lactation were not associated. This was expected, because most of the IMI cured spontaneously during the first 2 wk after calving, and is in line with the results of Tomazi et al. (2015). The fact that the negative association between daily qMY and IMI caused by major pathogens was not significant can be attributed in part to a lack of power. Part of the lack of power in our study is explained by the smaller than expected number of IMI during the sampling period and the very small numerical difference in estimated MY between NAS-infected and noninfected quarters. To avoid a lack of power, future 
studies with larger numbers of samples could be more easily conducted due to the availability of new diagnostic techniques, such as the MALDI-TOF MS, which allows for a more rapid, much cheaper, and reliable identification of NAS to the species level (Cameron et al., 2018).

Results of bacteriological culturing showed that of the 68 quarters subclinically infected with NAS at the first sampling day, only $23.5 \%$ were still infected with NAS at the second sampling day, whereas $70.6 \%$ had spontaneously cured. This high level of spontaneous cure is slightly higher than reported by McDougall (1998), Wilson et al. (1999), and Nyman et al. (2018), and almost twice the level $(39.5 \%)$ observed in the study of Taponen et al. (2006). A first explanation for this discrepancy might be the different type of sampling; in the current study, all quarters were sampled after calving, whereas in the study of Taponen et al. (2006), field mastitis cases were sampled. A second reason might be the difference in interval between 2 samplings: 30 $\mathrm{d}$ in Taponen et al. (2006) compared with $14 \mathrm{~d}$ in our study. The longer interval potentially increases the risk of re-infection. It is also important to consider that the ability to persist in the udder for longer periods varies greatly among different NAS species (Aarestrup and Jensen, 1997; Chaffer et al., 1999). At least 11 different NAS species have been found to cause persistent IMI (Staph. chromogenes, Staph. simulans, Staph. epidermidis, Staph. haemolyticus, Staph. xylosus, Staph. cohnii, Staph. capitis, Staph. nepalensis, Staph. warneri, Staph. hyicus, and Staph. saprophyticus; Thorberg et al., 2009; Mørk et al., 2012; Fry et al., 2014; Nyman et al., 2018), with several strains within each species being able to cause these persistent infections (Mørk et al., 2012).

None of the quarters infected with a NAS species at the first sampling day became infected with a major pathogen at the second sampling day. Several studies have reported on the potential protective effects of IMI with NAS against IMI with major pathogens; for example, by production of bacteriocins (Nascimento et al., 2005; Braem et al., 2014; Carson et al., 2017). This might partly explain the higher MY in animals having an IMI with NAS in the study of Piepers et al. (2010).

Besides the high spontaneous cure rate in the period between the first and second sampling days, 15 of the 220 noninfected quarters acquired a nIMI with a NAS species by the second sampling day. These nIMI cases came with a higher qSCC during the first 4 mo of lac-

Table 7. Final linear mixed regression model describing the association between the natural log-transformed quarter milk SCC (qLnSCC; outcome variable) during the first 4 mo of lactation and transient, persistent, and new quarter-level IMI (qIMI) with Staphylococcus chromogenes on the first (1-4 DIM) and second (15-18 DIM) sampling days after calving (main predictor of interest) of 202 quarters from 74 dairy heifers in 3 herds

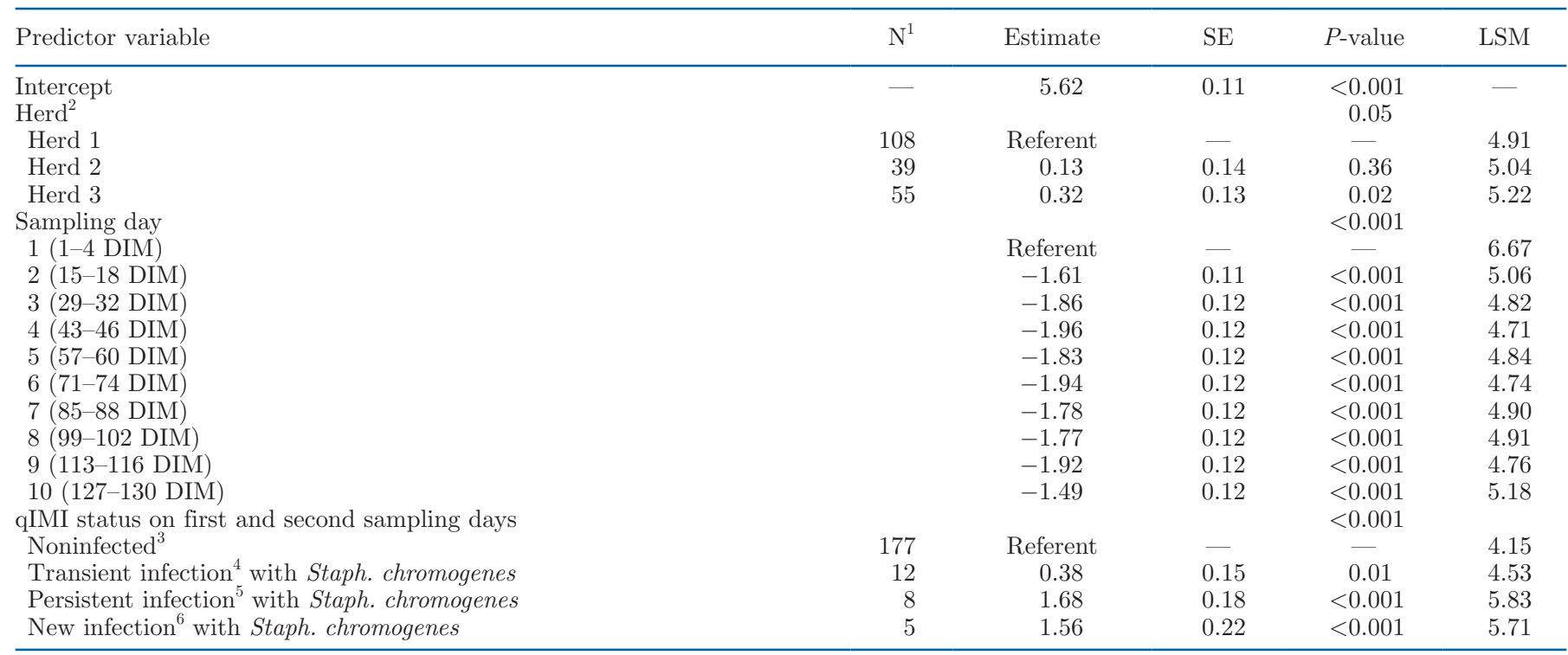

${ }^{1}$ Number of quarters.

${ }^{2}$ Herd was forced in the model to correct for potential clustering of heifers within herds.

${ }^{3}$ Based on a culture-negative test result on the first and second sampling days.

${ }^{4}$ Based on a culture-positive test result for a bacterial species at the first sampling day and a culture-negative test result for the same bacterial species at the second sampling day.

${ }^{5}$ Based on a culture-positive test result for the same bacterial species on the first and second sampling days.

${ }^{6}$ Based on a culture-negative test result at the first sampling day and a culture-positive test result at the second sampling day. 
Table 8. Final linear mixed regression model describing the association between the daily quarter milk yield (qMY; outcome variable) during the first 4 mo of lactation and transient, persistent, and new quarter-level IMI (qIMI) with Staphylococcus chromogenes at the first (1-4 DIM) and second (15-18 DIM) sampling day after calving (main predictor of interest) of 202 quarters from 74 dairy heifers in 3 herds

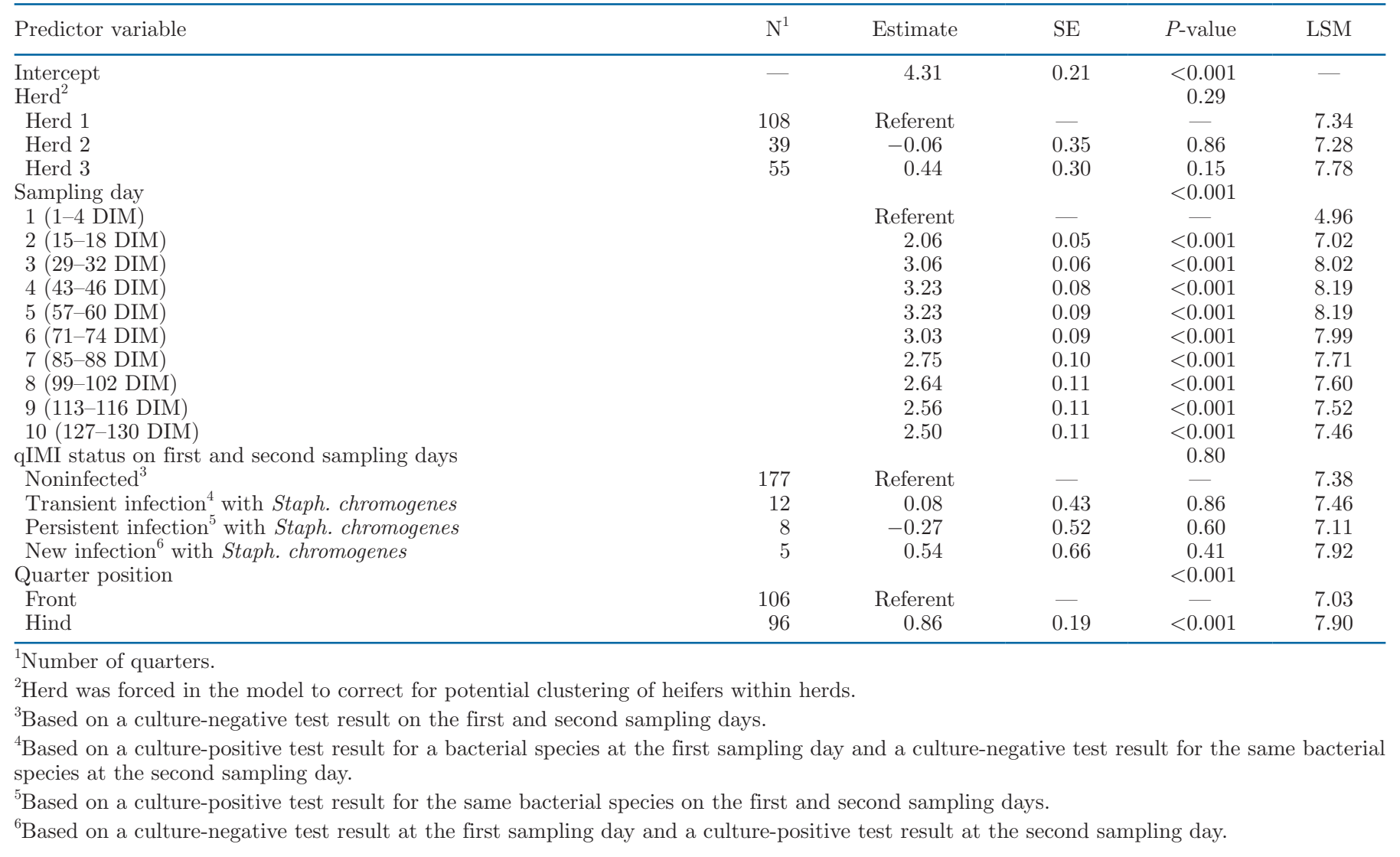

tation compared with quarters having a tIMI. Of the 15 nIMI cases, 5 were caused by $S$. chromogenes, and the qSCC until 130 DIM was not significantly lower compared with quarters having a pIMI with $S$. chromogenes. A potential explanation could be that these nIMI cases at the second sampling day might persist for longer in the lactation. This highlights the importance of preventing heifer mastitis, not only at the end of gestation and around calving but also during lactation. In our previous study (Valckenier et al., 2019), the effect of NAS IMI on the qSCC during the first 4 mo of lactation was underestimated because it was determined based only on IMI status at 1 to 4 DIM. Thus, quarters having a nIMI at the second sampling day were considered to be among the noninfected quarters at 1 to 4 DIM. These results stress the importance of determining IMI status not only within the first days after calving but also at a later time point.

Interestingly, quarters having a nIMI with NAS at the second sampling day had the highest daily qMY in the first 4 mo of lactation, although the difference was not significant, most probably due to the small number of samples. This raises the question of whether animals having the highest (genetic) predisposition are more susceptible for IMI with NAS, or whether these NAS IMI might have a protective effect against IMI with major pathogens, which partly explained the higher MY in NAS-infected heifers (Piepers et al., 2010). Our previous findings showed no difference in prolactin level in milk from NAS-infected quarters compared with noninfected quarters (Valckenier et al., 2019), which puts the positive effect of NAS IMI on milk yield further under debate. More research is needed to investigate the infection dynamics of NAS IMI further into lactation to fully understand the impact (and potential protective effects) of these infections for milk production and udder health.

\section{ACKNOWLEDGMENTS}

The authors gratefully acknowledge the farmers who cooperated in this work. None of the authors have a financial of personal relationship with other people or organizations that could inappropriately influence or bias the content of the paper. 


\section{REFERENCES}

Aarestrup, F. M., and N. E. Jensen. 1997. Prevalence and duration of intramammary infection in Danish heifers during the peripartum period. J. Dairy Sci. 80:307-312. https://doi.org/10.3168/jds .S0022-0302(97)75939-3.

Braem, G., B. Stijlemans, W. Van Haken, S. De Vliegher, L. De Vuyst, and F. Leroy. 2014. Antibacterial activities of coagulase-negative staphylococci from bovine teat apex skin and their inhibitory effect on mastitis-related pathogens. J. Appl. Microbiol. 116:10841093. https://doi.org/10.1111/jam.12447.

Cameron, M., J. Perry, J. R. Middleton, M. Chaffer, J. Lewis, and G. P. Keefe. 2018. Short communication: Evaluation of MALDI-TOF mass spectrometry and a custom reference spectra expanded database for the identification of bovine-associated coagulase-negative staphylococci. J. Dairy Sci. 101:590-595. https://doi.org/10.3168/ jds.2017-13226.

Capurro, A., K. Artursson, K. P. Waller, B. Bengtsson, H. EricssonUnnerstad, and A. Aspán. 2009. Comparison of a commercialized phenotyping system, antimicrobial susceptibility testing, and tuf gene sequence-based genotyping for species-level identification of coagulase-negative staphylococci isolated from cases of bovine mastitis. Vet. Microbiol. 134:327-333. https://doi.org/10.1016/j vetmic.2008.08.028.

Carson, D. A., H. W. Barkema, S. Naushad, and J. De Buck. 2017. Bacteriocins of non-aureus staphylococci isolated from bovine milk. Appl. Environ. Microbiol. 83:e1015-17. https://doi.org/10 .1128/AEM.01015-17.

Chaffer, M., G. Leitner, M. Winkler, A. Glickman, O. Krifucks, E. Ezra, and A. Saran. 1999. Coagulase-negative staphylococci and mammary gland infections in cows. Zentralbl. Veterinarmed. B 46:707-712. https://doi.org/10.1046/j.1439-0450.1999.00289.x.

Compton, C. W., C. Heuer, K. Parker, and S. McDougall. 2007. Risk factors for peripartum mastitis in pasture-grazed dairy heifers. J. Dairy Sci. 90:4171-4180. https://doi.org/10.3168/jds.2006-882.

Condas, L. A. Z., J. De Buck, D. B. Nobrega, D. A. Carson, S. Naushad, S. De Vliegher, R. N. Zadoks, J. R. Middleton, S. Dufour, J. P. Kastelic, and H. W. Barkema. 2017a. Prevalence of non-aureus staphylococci species causing intramammary infections in Canadian dairy herds. J. Dairy Sci. 100:5592-5612. https://doi.org/10 $.3168 /$ jds.2016-12478.

Condas, L. A. Z., J. De Buck, D. B. Nobrega, D. A. Carson, J.-P. Roy, G. P. Keefe, T. J. DeVries, J. R. Middleton, S. Dufour, and H. W. Barkema. 2017b. Distribution of non-aureus staphylococci species in udder quarters with low and high somatic cell count, and clinical mastitis. J. Dairy Sci. 100:5613-5627. https://doi.org/10.3168/ jds.2016-12479.

De Visscher, A., S. Piepers, F. Haesebrouck, and S. De Vliegher. 2016. Intramammary infection with coagulase-negative staphylococci at parturition: Species-specific prevalence, risk factors, and effect on udder health. J. Dairy Sci. 99:6457-6469. https://doi.org/10.3168/ jds.2015-10458.

De Vliegher, S., L. K. K. Fox, S. Piepers, S. McDougall, and H. W. W. Barkema. 2012. Invited review: Mastitis in dairy heifers: Nature of the disease, potential impact, prevention, and control. J. Dairy Sci. 95:1025-1040. https://doi.org/10.3168/jds.2010-4074.

Dohoo, I. R. R., J. Smith, S. Andersen, D. F. F. Kelton, S. Godden, and Mastitis Research Workers' Conference. 2011. Diagnosing intramammary infections: Evaluation of definitions based on a single milk sample. J. Dairy Sci. 94:250-261. https://doi.org/10.3168/jds .2010-3559.

Fox, L. K. 2009. Prevalence, incidence and risk factors of heifer mastitis. Vet. Microbiol. 134:82-88. https://doi.org/10.1016/j.vetmic 2008.09.005

Fry, P. R. R., J. R. R. Middleton, S. Dufour, J. Perry, D. Scholl, and I. Dohoo. 2014. Association of coagulase-negative staphylococcal species, mammary quarter milk somatic cell count, and persistence of intramammary infection in dairy cattle. J. Dairy Sci. 97:48764885. https://doi.org/10.3168/jds.2013-7657.

Gröhn, Y. T., D. J. J. Wilson, R. N. Gonzalez, J. A. A. Hertl, H. Schulte, G. Bennett, and Y. H. H. Schukken. 2004. Effect of pathogen-specific clinical mastitis on milk yield in dairy cows. J. Dairy Sci. 87:3358-3374. https://doi.org/10.3168/jds.S0022 $-0302(04) 73472-4$

Heikkilä, A.-M., E. Liski, S. Pyörälä, and S. Taponen. 2018. Pathogen-specific production losses in bovine mastitis. J. Dairy Sci. 101:9493-9504. https://doi.org/10.3168/jds.2018-14824.

Hogan, J. S., R. N. Gonzales, R. J. Harmon, S. C. Nickerson, S. P. Oliver, J. W. Pankey, and K. L. Smith. 1999. Laboratory Handbook on Bovine Mastitis. National Mastitis Council, Madison, WI.

McDougall, S. 1998. Efficacy of two antibiotic treatments in curing clinical and subclinical mastitis in lactating dairy cows. N. Z. Vet. J. 46:226-232. https://doi.org/10.1080/00480169.1998.36094.

Mørk, T., H. J. Jørgensen, M. Sunde, B. Kvitle, S. Sviland, S. Waage, and T. Tollersrud. 2012. Persistence of staphylococcal species and genotypes in the bovine udder. Vet. Microbiol. 159:171-180. https: //doi.org/10.1016/j.vetmic.2012.03.034.

Nascimento, J. D. S., P. C. Fagundes, M. A. V. D. P. Brito, K. R. Netto Dos Santos, and M. D. C. D. F. Bastos. 2005. Production of bacteriocins by coagulase-negative staphylococci involved in bovine mastitis. Vet. Microbiol. 106:61-71. https://doi.org/10.1016/ j.vetmic.2004.10.014.

Nyman, A.-K., C. Fasth, and K. Persson Waller. 2018. Intramammary infections with different non-aureus staphylococci in dairy cows. J. Dairy Sci. 101:1403-1418. https://doi.org/10.3168/jds.2017-13467.

Oliver, S. P. P., M. J. J. Lewis, B. E. E. Gillespie, H. H. H. Dowlen, E. C. C. Jaenicke, and R. K. K. Roberts. 2003. Prepartum antibiotic treatment of heifers: Milk production, milk quality and economic benefit. J. Dairy Sci. 86:1187-1193. https://doi.org/10.3168/jds .S0022-0302(03)73702-3.

Paradis, M. E., E. Bouchard, D. T. Scholl, F. Miglior, and J. P. Roy. 2010. Effect of nonclinical Staphylococcus aureus or coagulase-negative staphylococci intramammary infection during the first month of lactation on somatic cell count and milk yield in heifers. J. Dairy Sci. 93:2989-2997. https://doi.org/10.3168/jds.2009-2886.

Persson Waller, K., A. Aspán, A. Nyman, Y. Persson, and U. Grönlund Andersson. 2011. CNS species and antimicrobial resistance in clinical and subclinical bovine mastitis. Vet. Microbiol. 152:112116. https://doi.org/10.1016/j.vetmic.2011.04.006.

Piepers, S., G. Opsomer, H. W. W. Barkema, A. de Kruif, and S. De Vliegher. 2010. Heifers infected with coagulase-negative staphylococci in early lactation have fewer cases of clinical mastitis and higher milk production in their first lactation than noninfected heifers. J. Dairy Sci. 93:2014-2024. https://doi.org/10.3168/jds .2009-2897.

Piepers, S., Y. H. H. Schukken, P. Passchyn, and S. De Vliegher. 2013. The effect of intramammary infection with coagulase-negative staphylococci in early lactating heifers on milk yield throughout first lactation revisited. J. Dairy Sci. 96:5095-5105. https://doi .org $/ 10.3168 / \mathrm{jds} .2013-6644$.

Piessens, V., S. De Vliegher, B. Verbist, G. Braem, A. Van Nuffel, L. De Vuyst, M. Heyndrickx, and E. Van Coillie. 2012. Intra-species diversity and epidemiology varies among coagulase-negative Staphylococcus species causing bovine intramammary infections. Vet. Microbiol. 155:62-71. https://doi.org/10.1016/j.vetmic.2011 .08 .005 .

Piessens, V., E. Van Coillie, B. Verbist, K. Supré, G. Braem, A. Van Nuffel, L. De Vuyst, M. Heyndrickx, and S. De Vliegher. 2011. Distribution of coagulase-negative Staphylococcus species from milk and environment of dairy cows differs between herds. J. Dairy Sci. 94:2933-2944. https://doi.org/10.3168/jds.2010-3956.

Pitkälä, A., M. Haveri, S. Pyörälä, V. Myllys, and T. Honkanen-Buzalski. 2004. Bovine mastitis in Finland 2001-Prevalence, distribution of bacteria, and antimicrobial resistance. J. Dairy Sci. 87:2433-2441. https://doi.org/10.3168/jds.S0022-0302(04)73366 -4 .

Schukken, Y. H., R. N. Gonzalez, L. L. Tikofsky, H. F. Schulte, C. G. Santisteban, F. L. Welcome, G. J. Bennett, M. J. Zurakowski, and R. N. Zadoks. 2009. CNS mastitis: Nothing to worry about? Vet. Microbiol. 134:9-14. https://doi.org/10.1016/j.vetmic.2008 .09 .014 . 
Supré, K., S. De Vliegher, O. C. C. Sampimon, R. N. N. Zadoks, M. Vaneechoutte, M. Baele, E. De Graef, S. Piepers, and F. Haesebrouck. 2009. Technical note: Use of transfer RNA-intergenic spacer PCR combined with capillary electrophoresis to identify coagulase-negative Staphylococcus species originating from bovine milk and teat apices. J. Dairy Sci. 92:3204-3210. https://doi.org/ 10.3168/jds.2008-1923.

Supré, K., F. Haesebrouck, R. N. N. Zadoks, M. Vaneechoutte, S. Piepers, and S. De Vliegher. 2011. Some coagulase-negative Staphylococcus species affect udder health more than others. J. Dairy Sci. 94:2329-2340. https://doi.org/10.3168/jds.2010-3741.

Taponen, S., J. Björkroth, and S. Pyörälä. 2008. Coagulase-negative staphylococci isolated from bovine extramammary sites and intramammary infections in a single dairy herd. J. Dairy Res. 75:422429. https://doi.org/10.1017/S0022029908003312.

Taponen, S., J. Koort, J. Björkroth, H. Saloniemi, and S. Pyörälä. 2007. Bovine intramammary infections caused by coagulase-negative staphylococci may persist throughout lactation according to amplified fragment length polymorphism-based analysis. J. Dairy Sci. 90:3301-3307. https://doi.org/10.3168/jds.2006-860.

Taponen, S., S. Nykäsenoja, T. Pohjanvirta, A. Pitkälä, and S. Pyörälä. 2016. Species distribution and in vitro antimicrobial susceptibility of coagulase-negative staphylococci isolated from bovine mastitic milk. Acta Vet. Scand. 58:12. https://doi.org/10.1186/s13028-016 -0193-8.

Taponen, S., H. Simojoki, M. Haveri, H. D. Larsen, and S. Pyörälä. 2006. Clinical characteristics and persistence of bovine mastitis caused by different species of coagulase-negative staphylococci identified with API or AFLP. Vet. Microbiol. 115:199-207. https:/ /doi.org/10.1016/j.vetmic.2006.02.001.

Tenhagen, B.-A., G. Köster, J. Wallmann, and W. Heuwieser. 2006. Prevalence of mastitis pathogens and their resistance against antimicrobial agents in dairy cows in Brandenburg, Germany. J. Dairy Sci. 89:2542-2551. https://doi.org/10.3168/jds.S0022 -0302(06)72330-X.

Thorberg, B.-M., M.-L. Danielsson-Tham, U. Emanuelson, and K. Persson Waller. 2009. Bovine subclinical mastitis caused by different types of coagulase-negative staphylococci. J. Dairy Sci. 92:4962-4970. https://doi.org/10.3168/jds.2009-2184.

Timms, L. L., and L. H. Schultz. 1987. Dynamics and significance of coagulase-negative staphylococcal intramammary infections. J. Dairy Sci. 70:2648-2657. https://doi.org/10.3168/jds.S0022 -0302(87)80335-1.

Tomazi, T., J. L. Goncalves, J. R. Barreiro, M. A. Arcari, and M. V. dos Santos. 2015. Bovine subclinical intramammary infection caused by coagulase-negative staphylococci increases somatic cell count but has no effect on milk yield or composition. J. Dairy Sci. 98:3071-3078. https://doi.org/10.3168/jds.2014-8466.

Tomazi, T., J. L. Goncalves, J. R. Barreiro, P. A. C. Braga, L. F. Prada e Silva, M. N. Eberlin, and M. V. dos Santos. 2014. Identification of coagulase-negative staphylococci from bovine intramammary infection by matrix-assisted laser desorption ionizationtime of flight mass spectrometry. J. Clin. Microbiol. 52:1658-1663. https://doi.org/10.1128/JCM.03032-13.

Valckenier, D., S. Piepers, A. De Visscher, R. M. Bruckmaier, and S. De Vliegher. 2019. Effect of intramammary infection with nonaureus staphylococci in early lactation in dairy heifers on quarter somatic cell count and quarter milk yield during the first 4 months of lactation. J. Dairy Sci. 102:6442-6453. https://doi.org/10.3168/ jds.2018-15913.

Vanderhaeghen, W., S. Piepers, F. Leroy, E. Van Coillie, F. Haesebrouck, and S. De Vliegher. 2014. Invited review: Effect, persistence, and virulence of coagulase-negative Staphylococcus species associated with ruminant udder health. J. Dairy Sci. 97:5275-5293. https://doi.org/10.3168/jds.2013-7775.

Vanderhaeghen, W., S. Piepers, F. Leroy, E. Van Coillie, F. Haesebrouck, and S. De Vliegher. 2015. Identification, typing, ecology and epidemiology of coagulase-negative staphylococci associated with ruminants. Vet. J. 203:44-51. https://doi.org/10.1016/j.tvjl 2014.11.001.

Wilson, D. J., R. N. Gonzalez, K. L. Case, L. L. Garrison, and Y. T. Gröhn. 1999. Comparison of seven antibiotic treatments with no treatment for bacteriological efficacy against bovine mastitis pathogens. J. Dairy Sci. 82:1664-1670. https://doi.org/10.3168/ jds.S0022-0302(99)75395-6.

Wilson, D. J., R. N. Gonzalez, and H. H. Das. 1997. Bovine mastitis pathogens in New York and Pennsylvania: Prevalence and effects on somatic cell count and milk production. J. Dairy Sci. 80:25922598. https://doi.org/10.3168/jds.S0022-0302(97)76215-5.

\section{ORCIDS}

D. Valckenier (1) https://orcid.org/0000-0002-7535-2778

S. Piepers @ https://orcid.org/0000-0003-4753-9321

S. De Vliegher @ https://orcid.org/0000-0001-6330-9062 